\title{
Barnyard Millet (Echinochloa Frumentacea Link) Cookies: Development, Value Addition, Consumer Acceptability, Nutritional and Shelf Life Evaluation.
}

\author{
*Surekha $N^{1}$, Ravikumar S Naik ${ }^{2}$ and Mythri S ${ }^{3}$, Rohini Devi ${ }^{4}$ \\ ${ }^{I}$ Department of Foods and Nutrition, College of Home Science, Marathwada Krishi Vidhyapeeth, Parbhani, \\ Maharashtra, ${ }^{2}$ Department of Agricultural Economics, UAS Dharwad, ${ }^{3}$ A.O, A.R.S. Annigeri, Dharwad, \\ ${ }^{4}$ Retd Professor and Head, of Foods and Nutrition, College of Home Science, Marathwada Krishi Vidhyapeeth, \\ Parbhani, Maharashtra, India.
}

\begin{abstract}
Millets have been neglected despite their nutritive value and therapeutic use. Barnyard millet is one of the underutilized nutritious minor millet. In developing countries like India with increasing urbanization, the demand for processed food is increasing popularly. Among them, bakery products particularly cookies command wide popularity in both urban and rural mass. Hence, an attempt was made to develop value added barnyard millet cookies with acceptable sensory attributes. Three types of cookies namely plain, pulse and vegetable cookies were developed. Plain cookies were developed by incorporating sago flour to barnyard millet flour at different levels. Further trials were conducted for value addition of plain cookies with pulses (soybean flour and green gram dhal flour) and dehydrated carrot gratings to barnyard millet flour at different levels to develop pulse and vegetable cookies respectively. Consumer acceptability studies were conducted for identifying the best accepted cookies. The nutritional and storage quality evaluation of the best accepted cookies were estimated by standard procedures. The findings indicated that plain cookies prepared with 100 per cent barnyard millet flour; pulse cookies with 10 per cent incorporation of soy bean flour and green gram dhal flour and vegetable cookies with 10 per cent incorporation of dehydrated carrot gratings were best accepted. Among various types of cookies, pulse cookies were most accepted by consumers ( $85 \%$ ). There was significant increase in the macro and micronutrient composition of cookies after incorporation of pulses and carrot gratings. The developed cookies had a shelf life of 45-60 days.
\end{abstract}

Key Words: Barnyard millet, Cookies, Consumer acceptability, Shelf life.

\section{Introduction}

Minor millets are a group of grassy plants with short slender culm and small grains possessing remarkable ability to survive under severe drought conditions. Millets have been food commodities since ancient times. Because of their important nutritional qualities, there is a need to revive their usage in daily diet. Millets can substitute major cereals for better health benefits. Barnyard millet (Echinochloa frumentacea Link) is an important minor millet having fair amounts of protein $(12 \%)$ that is highly digestible $(81.13 \%)$ coupled with low carbohydrate content $(58.56 \%$ ) of slow digestibility ie., $25.88 \%$ (Veena,2003). The dietary fiber is an important phytochemical component of barnyard millet (13\% total dietary fiber with 4.66 and $8.18 \%$ of soluble and insoluble fractions, respectively) that could be considered in the management of disorders like diabetes mellitus, obesity, hyperlipidemia, etc

Supplementation of cereal based products with millets has become increasingly popular due to nutritional and economic advantages. With proper preparation, 30 per cent of minor millets can be gainfully substituted for value added foods such as bakery products, extruded foods and allied mixes for the convenient preparation by rural and town folk at low cost. Thus the characteristic nature of minor millet with high yielding capacity, disease resistant, tolerant to adverse conditions and with better nutritive value in terms of complex carbohydrate and high dietary fiber render their suitability for the development of convenience, therapeutic and Ready-To-Eat (RTE) products. Further, in the present existing situation of the society it is the need of the day to exploit the positive nutritional benefits of millets and popularize them among all sectors of the society for achieving nutritional and therapeutic food security.

Thus, for the health conscious genera of the present world, minor millet especially Barnyard millet is perhaps one more addition to the existing list of healthy foods, owing to its nutritional superiority. Apart from this, the grain has high utilization potential owing to its excellent capacity to blend with other food grains without imparting any off flavor or aftertaste. Thus the millet can be incorporated in traditional foods and valuarized to novel food uses (Veena, 2003). Hence, the present investigation was undertaken to develop barnyard millet (Echinochloa frumentacea Link.) based value added cookies, consumer acceptability, nutritional and shelf life evaluation. 


\section{Materials And Methods}

Processing of raw ingredients: Barnyard millet constituted the main ingredient and other ingredients such as soybean, green gram dhal and dehydrated carrots were added either as a source of lysine, antioxidants, minerals, dietary fiber or hypoglycemic constituents. All the ingredients after suitable processing were stored in air tight containers for further use.

Product development: Three types of cookies were developed namely plain, pulse and vegetable cookies with barnyard millet flour. In all the three types of cookies amount of sugar (25 gm) and fat (25 gm) were kept constant.

For development of plain cookies, sago flour at the levels of 10, 15 and 20 per cent was taken and one basic cookie with 100 per cent barnyard millet was prepared. Three variations of pulse cookies were developed. Each variation comprised of barnyard millet flour, soybean flour and green gram dhal in different ratio as 40:5:5 (variation I), 30:10:10 (variation II) and 20:15:15 (variation III). Three variations of vegetable cookies were developed each variation comprised of barnyard millet and dehydrated carrot gratings in the ratio of 40:10 (variation I), 35:15 (variation II) and 30:20 (variation III) were taken.

Organoleptic evaluation: The value added barnyard millet cookies were evaluated for organoleptic quality attributes by ranking the responses using a 5 point Ranking Scale (Amerine et al., 1965) by a panel of fifteentwenty semi-trained judges from Department of Foods and Nutrition, College of Home Science, Parbhani (M.S.).

Consumer acceptance: An evaluation proforma was developed to note the consumer acceptance and the response of consumers towards the developed cookies was recorded. Consumers were requested to give their individual opinion/acceptance about the developed cookies. The individuals were given separate proforma to record their observation.

Nutritional quality: The proximate principles namely protein, fat, carbohydrate, total ash, crude fiber, vitamins such as vitamin $\mathrm{C}$, total and $\beta$-carotene and minerals such as iron, calcium, magnesium and phosphorus content of all the three types of cookies has been assessed following the standard AOAC methods (Anon,1990).

Each selected developed value added cookies were analyzed in triplicate for moisture, protein, fat, total mineral, iron, calcium, magnesium, phosphorus, vitamin $\mathrm{C}$, total and $\beta$-carotene and total and reducing sugars. Moisture, fat and total minerals were estimated by AOAC (2005) method. The crude fibre in developed cookies were analysed by the procedure given by AOAC (1990). While protein and carbohydrate content was found out by (NIN, 1983). The energy content of value added cookies were computed by summing up the values obtained by multiplying the values with Atwater constants for carbohydrates, crude fat and protein with the 4, 9 and 4, respectively. The products were analysed for total sugars using Anthrone method (Thayumanavan and Sadasivam, 1984). Reducing sugars were determined by Nelson-Somogyi method (Somogyi, 1952). Vitamin C by titration method (A.O.A.C. 1984) and total and $\beta$-carotene was estimated by procedures given by Zakaria (1979). Iron, calcium and magnesium were analyzed by Atomic Absorption Spectrophotometer (AAS) (Model:AAS Analyst 700). Phosphorus was calculated by using food composition tables (Gopalan et al., 2004). Storage Quality of developed Products: Triplicate samples of value added cookies $(250 \mathrm{~g})$ were packed in two different kinds of packaging materials viz., polythene and aluminum laminated pouches and heat sealed and stored at ambient conditions of $28-30^{\circ} \mathrm{C}$ for two months. The storage qualities of cookies were evaluated in terms of visual observation, moisture uptake, free fatty acid and organoleptic quality at fifteen days intervals. Free fatty acid content of cookies was estimated by titrating the samples against potassium hydroxide $(0.01 \mathrm{~N})$ in presence of phenolphthalein indicator (Anon, 1983). The cookies were evaluated for organoleptic quality.

Statistical analysis: The analysis of variance (ANOVA) was used to find out significant differences between the variations for different sensory characters, nutrient content and also to assess the storage quality of developed cookies at different intervals in two different packages (Panse and Sukhatme, 1985).

\section{Results And Discussion}

Trials for standardization of cookies carried out for inclusion of different ingredients revealed that plain cookies developed by utilizing 100 per cent barnyard millet flour was highly acceptable. The mean scores ranged from 3.97 to 4.20 with lowest score for taste (3.97) and highest score for color (4.20). There was nonsignificant difference in all the sensory parameters among the cookies prepared with different variations of sago flour (Table 1). 
Table 1: Acceptability scores of plain cookies

\begin{tabular}{|c|c|c|c|c|c|}
\hline \multirow{2}{*}{ Variations } & \multicolumn{5}{|c|}{ Mean value of sensory score } \\
\hline & Color & Taste & Texture & Flavor & $\begin{array}{c}\text { Overall } \\
\text { acceptability }\end{array}$ \\
\hline $\mathrm{I}$ & 4.20 & 4.00 & 4.30 & 4.10 & 4.30 \\
\hline II & 4.30 & 3.80 & 4.10 & 3.80 & 3.90 \\
\hline III & 4.40 & 4.40 & 4.30 & 4.40 & 4.40 \\
\hline IV & 3.90 & 3.70 & 4.00 & 3.80 & 3.80 \\
\hline Mean & 4.20 & 3.97 & 4.17 & 4.02 & 4.10 \\
\hline $\mathrm{SE}+$ & 0.25 & 0.23 & 0.25 & 0.26 & 0.21 \\
\hline $\mathrm{CD}$ & NS & NS & NS & NS & NS \\
\hline
\end{tabular}

NS - Non Significant

Cookies prepared with different levels of incorporation of pulses to barnyard millet flour are presented in table 2. There was significant difference among all variations with respect to all sensory parameters. The Mean scores for acceptability ranged from 3.60 (color) to 4.06 (texture). Overall sensory scores of pulse cookies revealed that cookies prepared with 10 per cent of incorporation of pulses was highly acceptable and scored highest (4.50) over the other two cookies. The sensory scores of variation II was significantly higher $(\mathrm{p}<0.05)$ than variation I for all the parameters. The scores of variation III were at par with variation II for all the sensory parameters. Variation III scored statistically higher $(\mathrm{p}<0.05)$ score for all the parameters as compared to variation I.

Table 2: Acceptability scores of pulse cookies

\begin{tabular}{|c|c|c|c|c|c|}
\hline \multirow{2}{*}{ Variations } & \multicolumn{5}{|c|}{ Mean value of sensory score } \\
\cline { 2 - 6 } & Color & Taste & Texture & Flavor & $\begin{array}{c}\text { Overall } \\
\text { acceptability }\end{array}$ \\
\hline I & 2.70 & 2.40 & 3.10 & 2.70 & 2.70 \\
\hline II & $4.10^{*}$ & $4.40^{*}$ & $4.60^{*}$ & $4.40^{*}$ & $4.50^{*}$ \\
\hline III & 4.00 & 4.10 & 4.50 & 4.40 & 4.40 \\
\hline Mean & $\mathbf{3 . 6 0}$ & $\mathbf{3 . 6 3}$ & $\mathbf{4 . 0 6}$ & $\mathbf{3 . 8 3}$ & $\mathbf{3 . 8 6}$ \\
\hline SE \pm & 0.16 & 0.20 & 0.14 & 0.15 & 0.16 \\
\hline CD & 0.46 & 0.60 & 0.42 & 0.46 & 0.46 \\
\hline \multicolumn{7}{r}{} \\
\hline
\end{tabular}

Cookies prepared with incorporation of dehydrated carrot (grated) to barnyard millet exhibited significant difference with respect to all sensory characters (table 3). The Mean scores for acceptability ranged from 3.06 to 3.40 with lowest score for flavor and highest score for texture and taste (3.40). Among the cookies prepared with incorporation of dehydrated carrot at different levels showed that cookies prepared with 10 per cent incorporation of carrot gratings scored highest for all sensory characters followed by 15 per cent incorporation i.e., variation II. Variation I had significantly higher $(\mathrm{p}<0.05)$ values over variation III with respect to all the sensory parameters. However, when compared between variation II and variation I, significant difference $(p<0.05)$ was noted only for color among all the sensory parameter. Scores of variation II and variation III were at par for all the sensory characters.

Table 3: Acceptability scores of vegetable cookies

\begin{tabular}{|c|c|c|c|c|c|}
\hline \multirow{2}{*}{ Variations } & \multicolumn{4}{|l|}{ Mean value of sensory score } \\
\cline { 2 - 6 } & Color & Taste & Texture & Flavor & $\begin{array}{l}\text { Overall } \\
\text { acceptability }\end{array}$ \\
\hline I & $4.10^{*}$ & $4.00^{*}$ & $4.00^{*}$ & $3.70^{*}$ & $3.75^{*}$ \\
\hline II & 3.10 & 3.50 & 3.50 & 3.00 & 3.40 \\
\hline III & 2.70 & 2.70 & 2.70 & 2.50 & 2.70 \\
\hline Mean & $\mathbf{3 . 3 0}$ & $\mathbf{3 . 4 0}$ & $\mathbf{3 . 4 0}$ & $\mathbf{3 . 0 6}$ & $\mathbf{3 . 2 8}$ \\
\hline SE \pm & 0.27 & 0.35 & 0.35 & 0.32 & 0.32 \\
\hline CD & 0.78 & 1.03 & 1.03 & 0.94 & 0.95 \\
\hline
\end{tabular}

*- Significant at $(\mathrm{p}<0.05$

The acceptability scores of different cookies developed from barnyard millet revealed that barnyard millet can be successfully used for development of cookies. Among plain cookies it was noted that 100 per cent barnyard millet flour cookies were highly accepted (table 1). Sago flour is usually used as a binding material 
due to its stickiness. Bhavyashree et al. (2008) used sago flour in combination with Pearl millet (Bajra) and developed papad. They reported high acceptability of papads with incorporation of sago flour. In the present study, as the sago flour increased acceptability decreased. Sago flour exhibits a sort of elasticity when combined with water and results in thickness. Not only doesn't that sago flour contribute to the dough stability due to lack of protein content. Further during heat treatment being 100 per cent starch the sago flour changes colour fast. Probably all these factors contributed for low acceptability of plain cookies developed with incorporation of sago flour. The results found in the present study are in line with the observation made by Zaidul et al. (2004). Anju and Sarita (2010) developed barnyard millet biscuits and compared their acceptability with foxtail millet flour and crude refined wheat flour (CRWF) and reported better acceptability for barnyard millet flour and foxtail millet flour over wheat biscuits. Balloli (2008) developed barnyard millet flour cookies with incorporation of garden cress seeds and found that cookies were highly acceptable at higher level of barnyard millet flour incorporation which is in line with the present study.

Among pulse cookies the incorporation of pulse i.e., soybean flour and green gram dhal flour in equal proportions at 10 per cent level for cookies resulted in significantly high overall acceptability (table 2). Though the other sensory characters exhibited non-significant difference, in general their sensory scores were high as compared to variation I and III, which supported the opinion that variation II is better accepted as compared to other two variations. The overall acceptability of variation II in pulse cookies was significantly high. These findings reveal that pulse incorporation in barnyard millet 10 per cent level for cookies is desirable and the better acceptability noted could be attributed to the sensory and chemical properties of both the pulses. Pulse cookies, variation II scored highest for texture (4.60) followed by overall acceptability (4.50) than variation I which contained only 5 per cent incorporation of each pulses. Oluwamukomi et al. (2011) also reported better acceptability of biscuits when soy flour incorporation increased. Lakshmi Devi and Khader (1997) developed vermicelli with pulse blends for geriatrics' where they have used three dhal flour i.e., black gram dhal, green gram and bengal gram flour at 25 per cent incorporation and reported better acceptability of green gram dhal flour over bengal gram flour. The variation I scored least marks for several sensory characters. This variation contained lowest incorporation of pulses as compared to variation II. The least scores could be attributed to low incorporation of pulses because the bland taste of barnyard millet flour is dominating the product. Several other studies reported less acceptability of developed products when 10 per cent of soybean was incorporated in the product as against 20 per cent incorporation (Deshpande et al., 2004 and Singh et al., 2004).

Variation III scored least acceptability over variation II probably due to more per cent of incorporation of soybean. According to Surarez et al. (1999) soy flour is high in oligosaccharide, raffinose, stachyose and is characterized by beany flavor that may be objectionable to some consumers. However, even in case of vegetable cookies it was also noted that the acceptability decreased as the incorporation of vegetable increased(table 3). Similar findings were also reported by Mridula et al. (2009) when biscuits were developed with incorporation of beetroot powder.

Table 4: Consumer acceptance of developed cookies $(n=60)$

\begin{tabular}{|c|c|c|c|c|c|c|c|c|c|c|}
\hline \multirow[t]{2}{*}{ Cookies } & \multicolumn{2}{|c|}{ Like extremely } & \multicolumn{2}{|c|}{ Like slightly } & \multicolumn{2}{|c|}{$\begin{array}{c}\text { Neither like nor } \\
\text { dislike }\end{array}$} & \multicolumn{2}{|c|}{ Dislike slightly } & \multicolumn{2}{|c|}{$\begin{array}{c}\text { Dislike } \\
\text { extremely }\end{array}$} \\
\hline & No & $\%$ & No & $\%$ & No & $\%$ & No & $\%$ & No & $\%$ \\
\hline Plain & 44 & 73.33 & 16 & 26.67 & - & - & - & - & - & - \\
\hline Pulse & 51 & 85.00 & 9 & 15.00 & - & - & - & - & - & - \\
\hline Vegetable & 48 & 80.00 & 10 & 16.67 & 2 & 3.33 & - & - & - & - \\
\hline
\end{tabular}

Table 4 shows the consumer acceptance of developed cookies. It is evident from the table 4 that maximum per cent of consumers 'like extremely' the pulse cookies $(85.00 \%)$ followed by vegetable cookies $(80.00 \%)$. However, when compared to pulse and vegetable cookies, 73.33 per cent of consumers 'liked extremely' the plain cookies. On the other hand, 15.00 per cent and 16.67 per cent of consumers 'liked slightly' the pulse and vegetable cookies respectively. Twenty seven (26.67\%) percent of the consumers had 'liked slightly' the plain cookies. However, very few consumers expressed as 'neither like nor dislike' category for vegetable cookies (3.33\%). However, none of the respondents were in 'dislike' category for developed cookies. Consumer acceptance studies of all the three types of fresh cookies revealed that none of the products were disliked or unacceptable by the consumers (Table 4).

\section{Nutrient composition of cookies}

Table 5 shows the macronutrient composition of value added cookies. The highest moisture content was recorded for pulse cookies and it was statistically $(<0.05)$ significant from other two cookies. Pulse cookies recorded 6.61 per cent of protein and it was statistically significant $(\mathrm{p}<0.05)$ from the plain and vegetable cookies. Fat content of cookies ranged from 23.6 per cent to 26.4 per cent and highest fat content was recorded for pulse cookies and lowest fat content was recorded for plain cookies. Total ash content of plain cookies was 
4.60 per cent while pulse cookies recorded 1.11 per cent and vegetable cookies recorded 0.66 per cent of total ash which differed significantly $(\mathrm{p}<0.05)$ over the other. The crude fiber content of all the three cookies ranged from 0.69 to 0.72 per cent with highest crude fiber being recorded by plain cookies $(0.72 \%)$ and lowest value being recorded for vegetable cookies $(0.69 \%)$. The plain cookies contained 64.78 per cent of carbohydrate while pulse cookies recorded 62.68 per cent and vegetable cookies recorded 66.51 per cent of carbohydrates.

The micronutrient content of value added cookies is presented in table 6 . The highest vitamin $\mathrm{C}$ content was recorded by vegetable cookies. The highest values for both $\beta$-carotene and total carotene content were recorded by vegetable cookies and it differed significantly $(p<0.05)$ from pulse cookies while it was at par with plain cookies. The highest iron content was recorded by vegetable cookies $(4.04 \mathrm{mg} / 100 \mathrm{~g})$ and it exhibited significantly higher $(\mathrm{p}<0.05)$ values than plain and pulse cookies. Highest calcium content was exhibited by vegetable cookies $(26.07 \mathrm{mg} / 100 \mathrm{~g})$. Plain and pulse cookies exhibited 10.70 and $22.65 \mathrm{mg} / 100 \mathrm{~g}$, of calcium respectively. The calcium content of all the three types of cookies differed significantly $(p<0.01)$. Mridula and Gupta (2008) incorporated Bajra flour at 10 per cent level and successfully developed biscuits. Oluwamukomi et al. (2011) also reported increase in protein content of biscuit from $8.41 \%$ to $11.39 \%$, when 10 per cent of soybean flour was incorporated. Soybean contains 33 per cent of carbohydrate, 18 per cent of fat and 40 per cent of protein (Akubor et al., 2006). Further the carrots were grated and dehydrated for incorporation which significantly contributed for higher content of other micronutrients (Walde et al. 1992).

Table 5: Macronutrient composition of developed cookies

\begin{tabular}{|c|c|c|c|c|c|c|c|}
\hline $\begin{array}{l}\text { Type Of } \\
\text { Cookies }\end{array}$ & $\begin{array}{l}\text { Moisture } \\
\mathbf{( g / 1 0 0 g})\end{array}$ & $\begin{array}{l}\text { Protein } \\
\mathbf{( g / 1 0 0 g})\end{array}$ & $\begin{array}{l}\text { Fat } \\
\mathbf{( g / 1 0 0 g})\end{array}$ & $\begin{array}{l}\text { Total } \\
\text { ash } \\
(\mathbf{g} / \mathbf{1 0 0 g})\end{array}$ & $\begin{array}{l}\text { Crude } \\
\text { fiber } \\
(\mathbf{g} / \mathbf{1 0 0 g})\end{array}$ & $\begin{array}{l}\text { Carbohydrat } \\
\mathbf{e} \\
\mathbf{( g / 1 0 0 g})\end{array}$ & $\begin{array}{l}\text { Energy } \\
\mathbf{( K c a l / 1 0 0 g})\end{array}$ \\
\hline Plain & 4.33 & 1.96 & 23.6 & $4.60 *$ & 0.72 & 64.78 & 479 \\
\hline Pulse & $4.70^{*}$ & $6.61 *$ & $26.4 *$ & 1.11 & 0.71 & 62.68 & $508 *$ \\
\hline Vegetable & 4.53 & 1.21 & 24.2 & 0.66 & 0.69 & 66.51 & 495 \\
\hline Mean & 4.52 & 3.26 & 24.73 & 2.05 & 0.70 & 64.65 & 494 \\
\hline SE+ & 0.08 & 0.38 & 0.75 & 0.08 & 0.02 & 0.76 & 4.81 \\
\hline CD & 0.24 & 1.16 & 2.28 & 0.26 & NS & NS & 14.48 \\
\hline
\end{tabular}

Table 6: Micronutrient composition of value added cookies

\begin{tabular}{|c|c|c|c|c|c|c|c|}
\hline $\begin{array}{l}\text { Type Of } \\
\text { Cookies }\end{array}$ & $\begin{array}{l}\text { Vitamin } \\
(\mathrm{mg} / 100 \mathrm{~g})\end{array} \quad C$ & 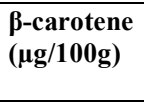 & $\begin{array}{l}\text { Total } \\
\text { carotene } \\
(\mu \mathrm{g} / 100 \mathrm{~g})\end{array}$ & $\begin{array}{l}\text { Iron } \\
(\mathrm{mg} / \mathbf{1 0 0 g})\end{array}$ & $\begin{array}{l}\text { Calcium } \\
(\mathrm{mg} / 100 \mathrm{~g})\end{array}$ & $\begin{array}{l}\text { Phosphorus } \\
\text { (mg/100g) }\end{array}$ & $\begin{array}{l}\text { Magnesium } \\
\text { (mg/100g) }\end{array}$ \\
\hline Plain & 1.162 & 116.25 & 1367.65 & 2.42 & 10.70 & 140.25 & 16.50 \\
\hline Pulse & 1.162 & 112.25 & 1250.00 & 2.50 & 22.65 & $193.75^{*}$ & $33.82 *$ \\
\hline Vegetable & $8.139 *$ & $117.50^{*}$ & $1385.29 *$ & $4.04 *$ & $26.07 *$ & 165.25 & 17.70 \\
\hline Mean & 3.487 & 115.33 & 1334.30 & 2.986 & 19.80 & 166.42 & 22.67 \\
\hline $\mathrm{SE}+$ & 0.21 & 0.98 & 36.14 & 0.04 & 0.44 & 2.44 & 0.69 \\
\hline $\mathrm{CD}$ & 0.63 & 2.97 & 108.77 & 0.14 & 1.34 & 7.34 & 2.10 \\
\hline
\end{tabular}

*significant at $(\mathrm{p}<0.05)$

\section{Storage quality}

The visual observation of stored cookies at the end of 60 days indicated no insect infestation in both the packages. On the other hand, there was a gradual deterioration in its colour. The cookies acquired a lighter shade as the storage period increased. There was a slight discoloration in contents of polythene pouch from 30 days onwards. Packaging materials have a role in determination of shelf life in terms of moisture uptake and altering the levels of free fatty acid and peroxide value thereby affecting the acceptability. However in the present investigation, the moisture content being low $(5 \%)$ contributed to the good storage stability of cookies. Analyses of moisture and free fatty acid content of cookies stored for 60 days revealed an increase in the levels of both the parameters (Fig $1 \& 2$ ) in the two different packaging materials used. Relatively higher levels of moisture and free fatty acid content were observed in cookies stored in polyethylene packages than the aluminum laminated packaging materials. This may be attributed to the hygroscopic nature of LDPE (lowdensity polyethylene) material, when stored for longer duration (Briston, 1980). The increased free fatty acid content of cookies in polythene pack could be due to higher oxygen transmission rate of polyethylene cover, thereby increased production of degradation compounds and due to exposure of foods in transparent pouches.

The scores for organoleptic characters of cookies stored in different packaging materials lowered with the increase in storage period (fig 3,4\&5). The scores for colour, flavor and texture although gradually and significantly decreased throughout the storage period from 30 day onwards, none of the products were unacceptable. Between the two packages, the scores for overall acceptability were significantly higher for 
aluminum-laminated pouch when compared to polyethylene pack. Barnyard millet based cookies possessed good storage quality, which is an important aspect of consumer acceptability.

\section{Conclusion}

Thus, from the present investigation it is clear that barnyard millet could be successfully value added. Hence, it can be concluded that the barnyard millet is a potential grain among the millets with superior nutrient content, could be a worthy addition to one's daily diet. However, further scientific investigations with regard to other novel foods can be carried out. Barnyard millet cookies possessing good storage quality can be of good commercial value.

Fig 1: Moisture content (\%) of stored cookies in different packaging materials

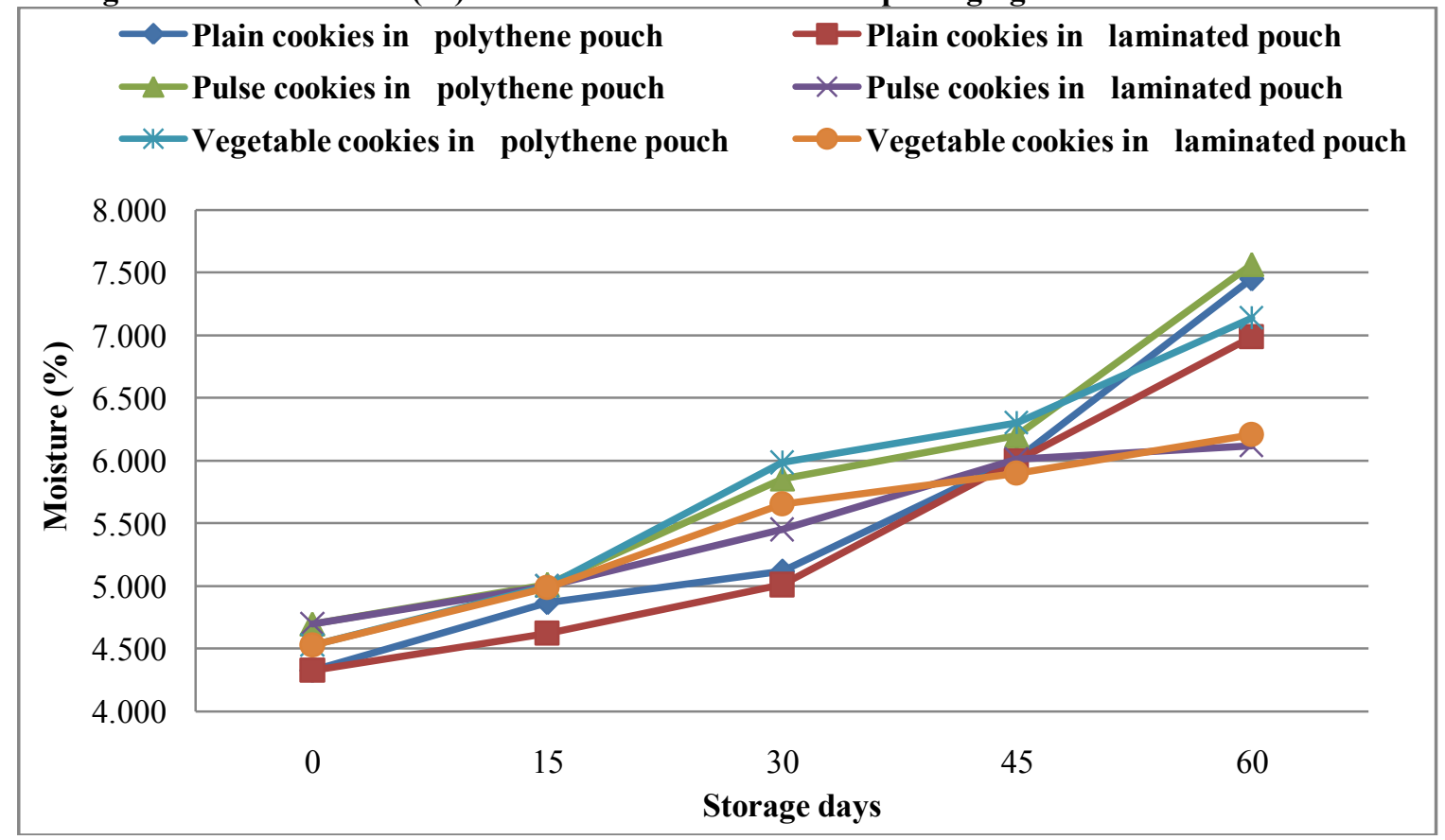

Fig 2: Free Fatty Acid (\% Oleic acid) content of stored cookies in different packaging materials

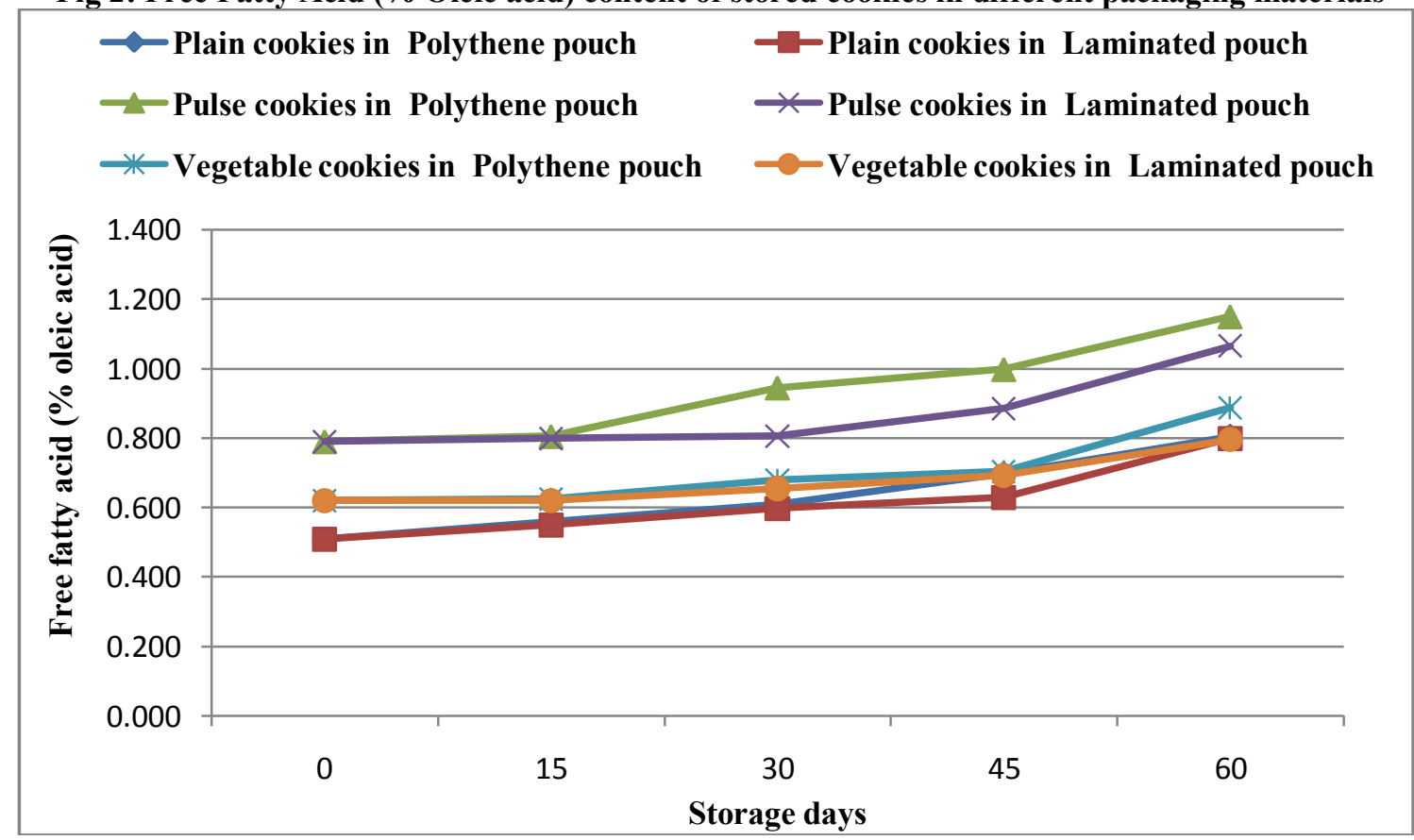

Fig 3: Effect of storage on sensory qualities of plain cookies 


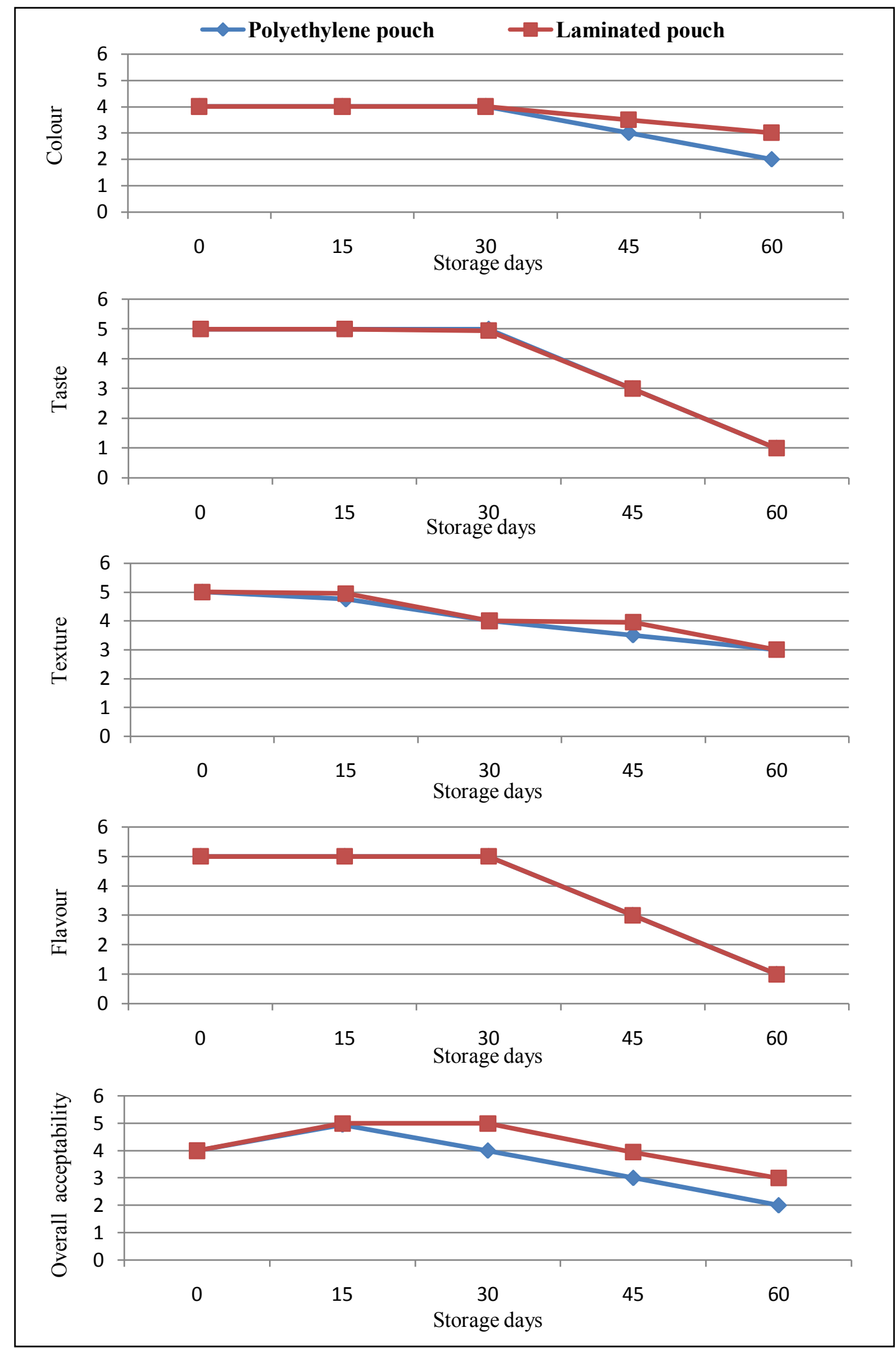

Fig 4: Effect of storage on sensory qualities of pulse cookies 


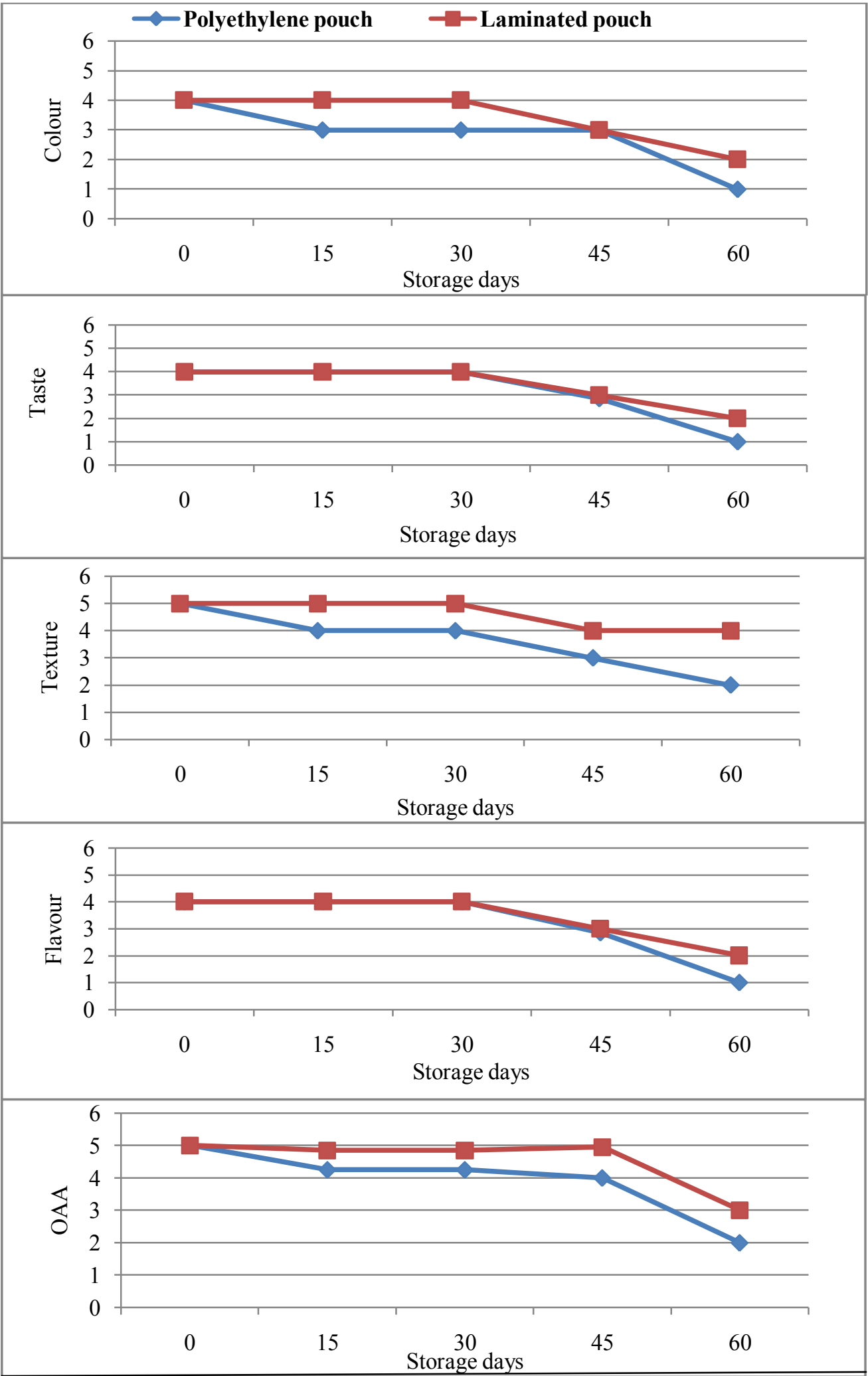

Fig 5: Effect of storage on sensory qualities of vegetable cookies 


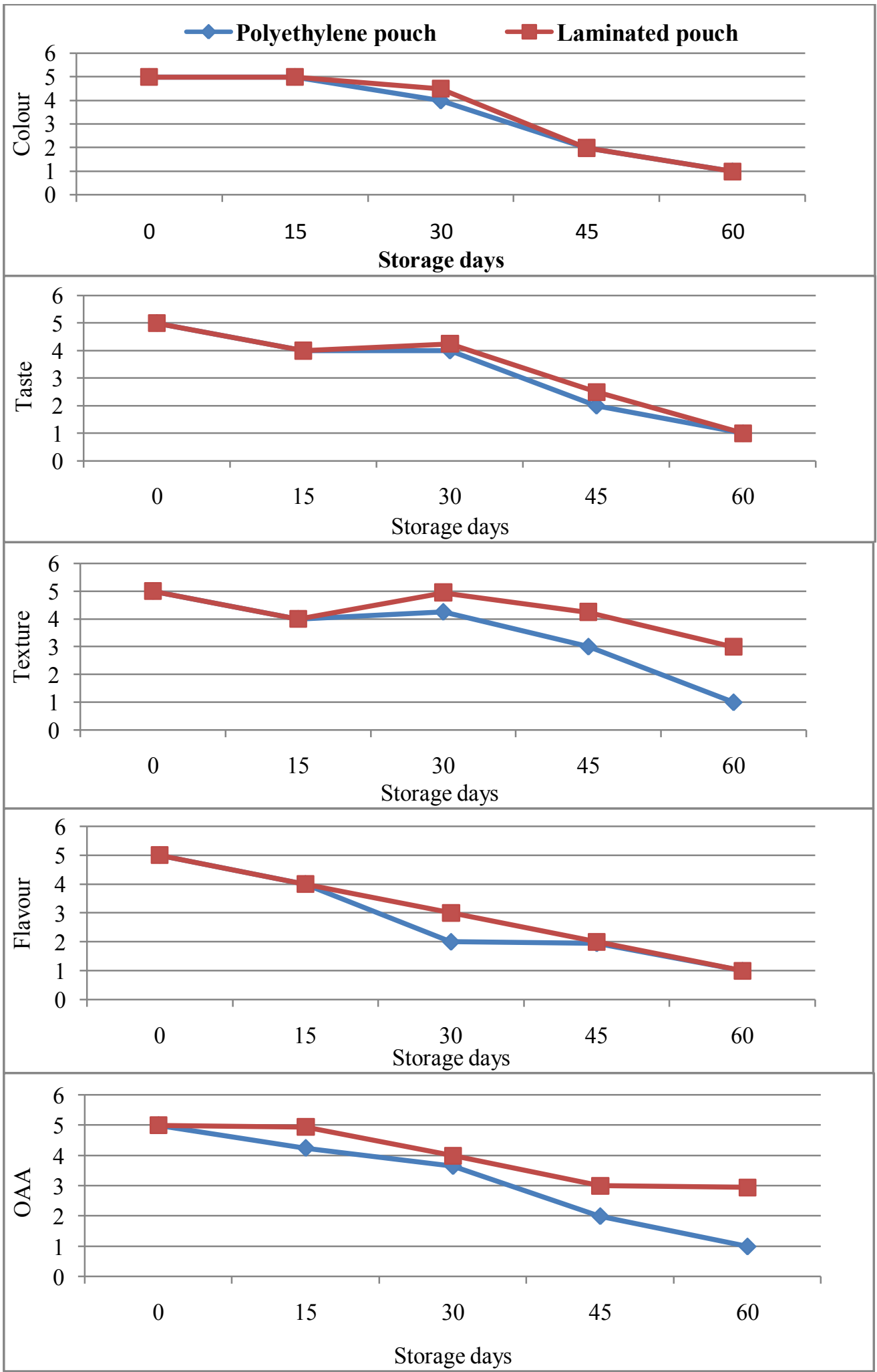

\section{Reference}

[1]. A.O.A.C. (1990). Official Methods of Analysis, $14^{\text {th }}$ ed. Association of official analytical chemists, Washington, DC

[2]. A.O.A.C. (2005). Official Methods of Analysis. Association of Official Analytical Chemists $18^{\text {th }}$ edition. Arlington, U.S.A

[3]. Akubor, P.I., Offonry, S.U. and Isolokwu, P.C. (2006). Effect of proportion of soy milk and pH on the quality attributes of soy warankasi - a Nigerian soft cheese. Journal of Food Science and Technology, 43:101-103.

[4]. Amerine, M.A., Pongborn, R.M. and Roessler, E.D. (1965). Principles of sensory evaluation of food. Academic Press., New York.

[5]. Anju., T. and Sarita, S. (2010). Suitability of Foxtail millet (Setaria italica) and Barnyard millet (Echinochloa frumentacea)for development of low glycaemic index biscuits. Mal. J. Nutr., 16(3):361-368.

[6]. Anon., (1983). Approved methods of American Association of cereal Chemists, $8^{\text {th }}$ Ed. AACC, The Association: St. Paul, MN 
[7]. Ballolli, U., Chimmad, B.V., Bharati, P. and Nagnur, S. (2011). Development of Nutty Barnyard millet (Echinochloa frumantacea Link) cookies. NAIP: National Symposium Recapturing Nutritious Millets for Health and Management of Diseases, UAS, Dharwad, December: 16-17, pp-42.

[8]. Bhavyashree, Rao, S.G. and Puttaraj, S. (2008). Formulation and preparation of bajra (Pennisetum typhoideum) papad. The Indian Journal of Nutrition Dietetics, 45:221-226.

[9]. Briston, J.H. (1980). Rigid plastic packaging. In : Developments in food packaging-1 Ed. Palling, S.J., Applied Science Publishers. England, pp: 42-43.

[10]. Deshpande, S., Bargale, P.C., Joshi, K.C., Singh, V. and Varghese, S. (2004). Enhancing the nutritive values of barley based sattu by soy-fortification. The Indian Journal of Nutrition and Dietetics, 41:146-159.

[11]. Gopalan, C., Ramasastry, B.V. and Balasubramanian, S.C. (2004). Nutritive value of Indian foods. National Institute of Nutrition, Indian Council of Medical Research, Hyderabad, India.

[12]. Lakshmidevi, K. and Khader, V. (1997). Preparation of vermicelli from wheat flour-pulse blends for geriatrics. Journal of Food Science and Technology, 34(6): 513-515.

[13]. Mridula, D. and Gupta, R.K. (2008). Effect of bajra flour on quality of biscuits fortified with defatted soy flour. Indian Journal of Nutrition and Dietetics, 45, 17-25.

[14]. Mridula, D., Naveen Kumar, M., Dilip Jain., Tyagi, S.K. and Rai, D.R. (2009). Effect of addition of beetroot powder on physical properties and acceptability of defatted soya flour fortified biscuits. . Indian Journal of Nutrition and Dietetics, 46, 59-69.

[15]. N.I.N. (1983). Manual of laboratory techniques. $2^{\text {nd }}$ edition,. Indian Council of Medical Research, Hyderabad.

[16]. Oluwamukomi, M.O., Oluwalana, I.B. and Akinbowale, O.F. (2011). Physicochemical and sensory properties of wheat-cassava composite biscuit enriched with soy flour. African Journal of Food Science, 5(2):50-56.

[17]. Panse, V.G. and Sukhatme, P.V. (1985). Statistical methods for agricultural workers. ICAR Publications. New Delhi.pp:58 -60 and 97-110.

[18]. Singh, G., Kawatra, A. and Sehgal, S. (2004). Nutritional evaluation of products developed from dried spinach leaves (Spinacea Oleracea). Indian Food Packer, January-February, pp:68-72.

[19]. Somogyi, N. (1952). J. Biol., Chem., 200:245

[20]. Surarez, F.I., Springfield, J., Furne, J.K., Lohramani, T.T., Kerr, P.S. and Levitt, M.D. (1999). Gay production in humans ingesting soybean flour derived from beans naturally low in oligosaccharides. American Journal of Clinical Nutrition, 69:135-139.

[21]. Thayumanavan, B. and Sadasivam, S. (1984). Qual. Plant Food Hum. Nutr., 34:253

[22]. Veena, B. (2003). Nutritional, functional and utilization studies on barnyard millet. M.H.Sc. Thesis, University of Agricultural Sciences, Dharwad.

[23]. Walde, W.G., Math, R.G., Chakkarvarthi, A. and Rao, D.G. (1992). Preservation of carrots by dehydration techniques. A Review. Indian Food Packer. 46:37-42.

[24]. Zaidul, I.S., Karim, A,A., Manan, D.M.A., Ariffin, A., Norulaini, N.A. and Omar, A.K. (2004). A farinograph study on the viscoelastic properties of sago/wheat flour dough systems. Journal of Science of Food and Agriculture, 84:616-622.

[25]. Zakaria, M., Simpson, K., Brown, P. R. and Kostulovic, A. (1979). Use of reversed phase HPLC analysis for the determination of provitamin - A carotenes in tomatoes. Journal of Chromatography, 176:179. 